\title{
Differences in fungi present in induced sputum samples from asthma patients and non-atopic controls: a community based case control study
}

\author{
Hugo Cornelis van Woerden ${ }^{1 *}$, Clive Gregory ${ }^{1 *}$, Richard Brown², Julian Roberto Marchesi ${ }^{2}$,
} Bastiaan Hoogendoorn ${ }^{1}$ and lan Price Matthews ${ }^{1}$

\begin{abstract}
Background: There is emerging evidence for the presence of an extensive microbiota in human lungs. It is not known whether variations in the prevalence of species of microbiota in the lungs may have aetiological significance in respiratory conditions such as asthma. The aim of the study was to undertake semi-quantitative analysis of the differences in fungal species in pooled sputum samples from asthma patients and controls.

Methods: Induced sputum samples were collected in a case control study of asthma patients and control subjects drawn from the community in Wandsworth, London. Samples from both groups were pooled and then tested for eukaryotes. DNA was amplified using standard PCR techniques, followed by pyrosequencing and comparison of reads to databases of known sequences to determine in a semi-quantitative way the percentage of DNA from known species in each of the two pooled samples.

Results: A total of 136 fungal species were identified in the induced sputum samples, with 90 species more common in asthma patients and 46 species more common in control subjects. Psathyrella candolleana, Malassezia pachydermatis, Termitomyces clypeatus and Grifola sordulenta showed a higher percentage of reads in the sputum of asthma patients and Eremothecium sinecaudum, Systenostrema alba, Cladosporium cladosporioides and Vanderwaltozyma polyspora showed a higher percentage of reads in the sputum of control subjects. A statistically significant difference in the pattern of fungi that were present in the respective samples was demonstrated using the Phylogenetic $(P)$ test $(P<0.0001)$.

Conclusion: This study is novel in providing evidence for the widespread nature of fungi in the sputum of healthy and asthmatic individuals. Differences in the pattern of fungi present in asthma patients and controls merit further investigation. Of particular interest was the presence of Malassezia pachydermatis, which is known to be associated with atopic dermatitis.
\end{abstract}

Keywords: Asthma, Sputum, Fungi, Case-control study

\section{Background}

The human lung has a surface area of around $50 \mathrm{~m}^{2}$ [1] and is in contact with more than 15,000 litres of air each day [2]. At each breath around 5,000 particles of dust are inhaled [3]. On average, the dust in the earth's atmosphere contains 10,000 to 100,000 organisms per gram of dust [4], some of which is in the 'respirable dust'

\footnotetext{
*Correspondence: vanwoerdenh1@cf.ac.uk; gregoryc1@cf.ac.uk ${ }^{1}$ Institute of Primary Care \& Public Health, Cardiff University School of Medicine, Neuadd Meirionnydd, Heath Park, Cardiff CF14 4YS, UK Full list of author information is available at the end of the article
}

fraction, consisting of particles smaller than $5 \mu \mathrm{m}$ [5]. This extensive exposure to the environment means that the lungs are a common portal for infection by viruses, bacteria, fungi, protozoa and other infectious agents.

Historically, healthy lungs were believed to be free of bacteria and that during infection organisms "gain a foothold in the normally sterile lung tissue" [6]. However, there is increasing evidence that microbiota are present even in healthy lungs [7]. This finding raises the possibility of a potential overlap between pathogenic and commensal microbiota in the respiratory tract.

\section{Biomed Central}

(c) 2013 van Woerden et al.; licensee BioMed Central Ltd. This is an Open Access article distributed under the terms of the Creative Commons Attribution License (http://creativecommons.org/licenses/by/2.0), which permits unrestricted use, distribution, and reproduction in any medium, provided the original work is properly cited. 
There is relatively little literature examining microbiota in human lungs. Tunney et al. [8] showed that approximately $50 \%$ of healthy individuals harbour between 1000 and 10,000 culturable anaerobic bacteria per $\mathrm{ml}$ of induced sputum A range of microbial species were also found in induced sputum at low numbers in another study which examined sputum from healthy subjects [9]. One previous study has been identified which used metagenomic culture independent genomic techniques and demonstrated that microbial communities in asthmatic airways were disordered, with pathogenic Proteobacteria more frequently found in the bronchi of asthmatics patients than in controls [10].

The current study further examines the role of atypical microbiota in respiratory disease. The study used molecular techniques to identify eukaryote species that were present in induced sputum samples taken from asthma patients and controls, living in Wandsworth, London. The aim of the study was to undertake semiquantitative analysis of the differences in fungal species present in pooled sputum samples from asthma patients and controls.

\section{Methods}

\section{Study population}

The study protocol was approved by Camden and Islington community local research ethics committee (ref 08/ H0722/540). All patients participating in the study supplied informed consent. This case control study from which the induced sputum samples were drawn has previously been described. Further information on the characteristics of the subjects in this study has been provided in that paper [11]. In summary, participants were residents of Wandsworth, London, and were primarily identified from the patient registers of two GP practices. Asthma patients were defined as those individuals who had a current diagnosis of asthma, for example, by being on the GP practice asthma register. Most of the asthma patients were on inhaled corticosteroids. Non-atopic controls were defined as individuals who on questioning did not report having current or previous asthma, eczema or hay fever. All participants competed a published questionnaire [12] to assess the risk of mould in the home. The questionnaire contained four questions: Is there any visible mould growth on your house? Is there any odour of mould or cellar-like musty air in your house? Is there any moisture stains in your house? Is there any water/moisture damage in your house?

\section{Sputum collection and DNA extraction}

Participants inhaled isotonic saline via an ultrasonic nebuliser. Globules of sputum were coughed up into petri dishes, spread on microscope slides and stained for microscopic examination. Approximately $5 \mathrm{~mm}^{2}$ areas were excised from each microscope slide. The samples were combined to yield two pooled samples for subsequent DNA extraction and PCR: asthma patients and control subjects. (A sample from one asthma patient was inadvertently included in the control set). DNA was subsequently extracted using the Zymo research pinpoint system (Zymo Research, Irvine, Ca) in accordance with manufacturer's instructions. The samples were taken from 30 asthma patients and 13 non-atopic control subjects involved in the case control study.

\section{Pyrosequencing of extracted DNA and statistical analysis} Extracted DNA was amplified using a PCR protocol for the partial 18S rRNA gene using the primer pair (Euk1a (5' CTG GTT GAT CCT GCC AG 3') and Euk516r (5' ACC AGA CTT GCC CTC C 3')) in accordance with previously described protocols $[13,14]$. The two pooled extract amplicons, from asthma patients and from controls, were sequenced using a 454 pyrosequencer by Research and Testing Inc, Lubbock, Texas, USA. DNA sequences were compared to the SILVA database of known eukaryotic $18 \mathrm{~S}$ rRNA gene sequences to determine in a semi-quantitative way the proportional distribution in each of the two samples.

The difference between the pattern of fungal species in each of the two pooled samples was compared using Unifrac $[15,16]$. This online software uses phylogenetic information to test whether or not two environments are significantly different. The software estimates the similarity between communities by measuring the number of changes that would be required to explain the differences in the distribution of sequences between the two environments.

\section{Results}

Study population and presence of mould in the home Patients had a mean age of 41.6 years (SD 14.9, range 18-65 years) and control participants a mean age of 35.7 years (SD 12.8, range $24-58$ years). The patient group was $40 \%$ male and the control group was $46 \%$ male.

A positive answer to at least one of the four questions regarding possible mould in the home was recorded in $30 \%(9 / 30)$ asthma patients and 15.4\% (2/13) of control subjects. Due to the small sample size, this relatively large difference was not statistically significant.

\section{Analysis of pyrosequencing data}

The differences based on the percent of total DNA reads of in the pooled samples from asthma patients and nonatopic controls are shown in Tables 1 and 2. A statistically significant difference in the pattern of fungi that were present in the respective samples was demonstrated using the Phylogenetic $(\mathrm{P})$ test $(\mathrm{P}<0.0001)$.

A total of 136 fungal species were identified in the induced sputum samples, with 90 species more common 
Table 1 Fungi that were more common in asthma patients than in control participants (difference in percent of DNA reads in descending order)

\begin{tabular}{|c|c|c|c|}
\hline Fungal species & $\begin{array}{l}\text { Control } \\
\text { participants }\end{array}$ & $\begin{array}{l}\text { Asthma } \\
\text { patients }\end{array}$ & Difference \\
\hline Psathyrella candolleana & 0.000 & 27.294 & 27.294 \\
\hline $\begin{array}{l}\text { Malassezia } \\
\text { pachydermatis }\end{array}$ & 0.000 & 21.651 & 21.651 \\
\hline Termitomyces clypeatus & 0.000 & 7.071 & 7.071 \\
\hline Grifola sordulenta & 0.000 & 4.489 & 4.489 \\
\hline Pycnoporus sp & 0.000 & 2.938 & 2.938 \\
\hline Phlebiopsis gigantean & 0.000 & 2.932 & 2.932 \\
\hline Dichostereum pallescens & 0.000 & 2.746 & 2.746 \\
\hline $\begin{array}{l}\text { Peniophorella } \\
\text { praetermissa }\end{array}$ & 0.168 & 2.617 & 2.449 \\
\hline Aspergillus zonatus & 0.016 & 1.959 & 1.942 \\
\hline $\begin{array}{l}\text { Acanthophysium } \\
\text { cerussatum }\end{array}$ & 0.000 & 1.825 & 1.825 \\
\hline Pleurotus ostreatus & 0.000 & 1.615 & 1.615 \\
\hline $\begin{array}{l}\text { Candelabrochaete } \\
\text { africana }\end{array}$ & 0.016 & 1.556 & 1.540 \\
\hline Basidiobolus ranarum & 0.000 & 1.510 & 1.510 \\
\hline Tapinella atrotomentosa & 0.000 & 1.487 & 1.487 \\
\hline Pleurocybella porrigens & 0.000 & 1.399 & 1.399 \\
\hline Debaryomyces hansenii & 0.000 & 1.294 & 1.294 \\
\hline Collybia tuberosa & 0.000 & 1.282 & 1.282 \\
\hline Galerina atkinsoniana & 0.000 & 1.230 & 1.230 \\
\hline $\begin{array}{l}\text { Punctularia } \\
\text { strigosozonata }\end{array}$ & 0.000 & 1.148 & 1.148 \\
\hline Elderia arenivaga & 0.000 & 1.143 & 1.143 \\
\hline $\begin{array}{l}\text { Pseudoarmillariella } \\
\text { ectypoides }\end{array}$ & 0.000 & 0.834 & 0.834 \\
\hline Pulcherricium caeruleum & 0.000 & 0.665 & 0.665 \\
\hline Tilletia goloskokovii & 0.000 & 0.618 & 0.618 \\
\hline Cerrena sp & 0.000 & 0.600 & 0.600 \\
\hline Serpula lacrymans & 0.000 & 0.571 & 0.571 \\
\hline Bondarcevomyces taxi & 0.000 & 0.554 & 0.554 \\
\hline Resinicium bicolor & 0.000 & 0.519 & 0.519 \\
\hline Cortinarius sodagnitus & 0.000 & 0.414 & 0.414 \\
\hline Trichaptum abietinum & 0.000 & 0.315 & 0.315 \\
\hline Chamaeota sinica & 0.000 & 0.262 & 0.262 \\
\hline Peziza vesiculosa & 0.000 & 0.239 & 0.239 \\
\hline Pterula echo & 0.000 & 0.204 & 0.204 \\
\hline Laccocephalum mylittae & 0.000 & 0.198 & 0.198 \\
\hline Coprinopsis cinerea & 0.000 & 0.198 & 0.198 \\
\hline Exidiopsis calcea & 0.000 & 0.187 & 0.187 \\
\hline Dioszegia fristingensis & 0.000 & 0.157 & 0.157 \\
\hline Inonotus baumii & 0.060 & 0.210 & 0.150 \\
\hline Hydnochaete olivacea & 0.000 & 0.134 & 0.134 \\
\hline Derxomyces boekhoutii & 0.000 & 0.128 & 0.128 \\
\hline $\begin{array}{l}\text { Xeromphalina } \\
\text { campanella }\end{array}$ & 0.000 & 0.117 & 0.117 \\
\hline
\end{tabular}

Table 1 Fungi that were more common in asthma patients than in control participants (difference in percent of DNA reads in descending order) (Continued)

\begin{tabular}{|c|c|c|c|}
\hline Pulchromyces fimicola & 0.000 & 0.111 & 0.111 \\
\hline Aspergillus oryzae & 0.000 & 0.099 & 0.099 \\
\hline Entoloma prunuloides & 0.000 & 0.099 & 0.099 \\
\hline Dioszegia zsoltii & 0.000 & 0.093 & 0.093 \\
\hline Basidiobolus haptosporus & 0.000 & 0.087 & 0.087 \\
\hline $\begin{array}{l}\text { Saccharomycopsis } \\
\text { fibuligera }\end{array}$ & 0.000 & 0.087 & 0.087 \\
\hline Galiella rufa & 0.000 & 0.082 & 0.082 \\
\hline Derxomyces simaoensis & 0.000 & 0.070 & 0.070 \\
\hline Mycoclelandia arenacea & 0.000 & 0.064 & 0.064 \\
\hline Steccherinum fimbriatum & 0.000 & 0.064 & 0.064 \\
\hline Austropaxillus $s p$ & 0.000 & 0.058 & 0.058 \\
\hline $\begin{array}{l}\text { Meyerozyma } \\
\text { guilliermondii }\end{array}$ & 0.000 & 0.058 & 0.058 \\
\hline Volvariella caesiotincta & 0.000 & 0.058 & 0.058 \\
\hline Galerina marginata & 0.000 & 0.052 & 0.052 \\
\hline Occultifur externus & 0.000 & 0.052 & 0.052 \\
\hline Hericium americanum & 0.000 & 0.047 & 0.047 \\
\hline Penicillium commune & 0.000 & 0.041 & 0.041 \\
\hline Volvopluteus earlei & 0.000 & 0.041 & 0.041 \\
\hline Gymnopus dryophilus & 0.000 & 0.029 & 0.029 \\
\hline Aspergillus terreus & 0.000 & 0.023 & 0.023 \\
\hline Tritirachium sp & 0.000 & 0.023 & 0.023 \\
\hline Gloiocephala aquatic & 0.000 & 0.023 & 0.023 \\
\hline Tricholoma matsutake & 0.000 & 0.023 & 0.023 \\
\hline Exidia uvapsassa & 0.000 & 0.017 & 0.017 \\
\hline Rhodocollybia maculate & 0.000 & 0.017 & 0.017 \\
\hline Lentinus sp & 0.000 & 0.017 & 0.017 \\
\hline $\begin{array}{l}\text { Teratosphaeria } \\
\text { acidotherma }\end{array}$ & 0.076 & 0.093 & 0.017 \\
\hline Taphrina deformans & 0.000 & 0.012 & 0.012 \\
\hline Antrodia vaillantii & 0.000 & 0.012 & 0.012 \\
\hline Aspergillus penicillioides & 0.000 & 0.012 & 0.012 \\
\hline Passalora vaginae & 0.000 & 0.012 & 0.012 \\
\hline Malassezia furfur & 0.000 & 0.012 & 0.012 \\
\hline Candida sp & 0.000 & 0.012 & 0.012 \\
\hline Piromyces $s p$ & 0.000 & 0.012 & 0.012 \\
\hline Paxillus vernalis & 0.000 & 0.012 & 0.012 \\
\hline Derxomyces mrakii & 0.000 & 0.012 & 0.012 \\
\hline Lasiodiplodia gonubiensis & 0.000 & 0.012 & 0.012 \\
\hline Teratosphaeria ohnowa & 0.005 & 0.012 & 0.006 \\
\hline Diversispora celata & 0.000 & 0.006 & 0.006 \\
\hline Geomyces destructans & 0.000 & 0.006 & 0.006 \\
\hline Coprinopsis sp & 0.000 & 0.006 & 0.006 \\
\hline $\begin{array}{l}\text { Chlamydosauromyces } \\
\text { punctatus }\end{array}$ & 0.000 & 0.006 & 0.006 \\
\hline Mortierella minutissima & 0.000 & 0.006 & 0.006 \\
\hline
\end{tabular}


Table 1 Fungi that were more common in asthma patients than in control participants (difference in percent of DNA reads in descending order) (Continued)

\begin{tabular}{llll}
\hline Saccobolus dilutellus & 0.000 & 0.006 & 0.006 \\
\hline Thanatephorus fusisporus & 0.000 & 0.006 & 0.006 \\
\hline Boletellus shichianus & 0.000 & 0.006 & 0.006 \\
\hline Puccinia poarum & 0.000 & 0.006 & 0.006 \\
\hline Mallocybe dulcamara & 0.000 & 0.006 & 0.006 \\
\hline Coniophora marmorata & 0.000 & 0.006 & 0.006 \\
\hline Trichosporon sp & 0.000 & 0.006 & 0.006 \\
\hline
\end{tabular}

in asthma patients and 46 species more common in control subjects, based on the percent of total DNA reads (see Figure 1). Psathyrella candolleana, Malassezia pachydermatis, Termitomyces clypeatus and Grifola sordulenta were particularly prevalent in the sputum of asthma patients and Eremothecium sinecaudum, Systenostrema alba, Cladosporium cladosporioides and Vanderwaltozyma polyspora were particularly prevalent in the sputum of control subjects. No other eukaryote species were identified in the sputum samples.

\section{Discussion}

The range of fungal species present in both asthma patients and control subjects was larger than expected. There were also clear differences in the pattern of fungal species between asthma patients and control subjects. The fungi Malassezia pachydermatis, was found in patients with asthma and not the control group. This organism has a known association with atopic conditions including atopic dermatitis [17]. However, there were no other obvious associations were identified in the published literature between asthma and the other fungi found in the pooled samples from the asthma patients. Two of the fungi most commonly found in the sputum of asthma patients (Termitomyces clypeatus and Psathyrella candolleana) represent members of the basidiomycete family [18]. The latter has been found in indoor dust [19] and one can speculate that fungal spores may have been inhaled within the home. It is possible that most of the fungi identified could have come from a single individual, or a small number of individuals, whose samples were heavily colonised by fungi.

Except for Cladosporium, the species identified in induced sputum are not commonly found in air samples examined using standard culture techniques [20]. Analysis of air samples using molecular techniques may demonstrate that these species are commonly present in the air, but this research has not been undertaken so far. Three out of four species detected in the sputum of asthma patients were from the macromycetes group (commonly known as mushrooms). Although asthma is
Table 2 Fungi that were more common in control participants than in asthma patients (difference in percent of DNA reads in descending order)

\begin{tabular}{|c|c|c|c|}
\hline Fungal species & $\begin{array}{l}\text { Control } \\
\text { participants }\end{array}$ & $\begin{array}{l}\text { Asthma } \\
\text { patients }\end{array}$ & Difference \\
\hline Eremothecium sinecaudum & 41.319 & 1.026 & 40.293 \\
\hline Systenostrema alba & 23.587 & 0.000 & 23.587 \\
\hline $\begin{array}{l}\text { Cladosporium } \\
\text { cladosporioides }\end{array}$ & 14.484 & 0.111 & 14.374 \\
\hline Vanderwaltozyma polyspora & 6.778 & 0.140 & 6.638 \\
\hline Entophlyctis helioformis & 2.976 & 0.064 & 2.912 \\
\hline Rozella allomycis & 3.009 & 0.198 & 2.811 \\
\hline Protomyces macrosporus & 1.971 & 0.082 & 1.890 \\
\hline Mortierella verticillata & 1.135 & 0.000 & 1.135 \\
\hline Pseudotaeniolina globosa & 1.086 & 0.210 & 0.876 \\
\hline Dothidea ribesia & 0.701 & 0.000 & 0.701 \\
\hline $\begin{array}{l}\text { Sporobolomyces } \\
\text { yunnanensis }\end{array}$ & 0.549 & 0.006 & 0.543 \\
\hline Teratosphaeria mexicana & 0.261 & 0.000 & 0.261 \\
\hline Myriangium duriaei & 0.179 & 0.000 & 0.179 \\
\hline Phaeobotryosphaeria visci & 0.174 & 0.000 & 0.174 \\
\hline Kionochaeta sp & 0.152 & 0.012 & 0.140 \\
\hline $\begin{array}{l}\text { Catenulostroma } \\
\text { chromoblastomycosum }\end{array}$ & 0.157 & 0.017 & 0.140 \\
\hline Phaeobotryon mamane & 0.125 & 0.000 & 0.125 \\
\hline Allomyces arbuscula & 0.125 & 0.000 & 0.125 \\
\hline Schizothyrium pomi & 0.109 & 0.000 & 0.109 \\
\hline Mycosphaerella endophytica & 0.103 & 0.000 & 0.103 \\
\hline Penidiella columbiana & 0.098 & 0.000 & 0.098 \\
\hline Aspergillus fumigatus & 0.174 & 0.087 & 0.086 \\
\hline Cladosporium sp & 0.081 & 0.000 & 0.081 \\
\hline Aleuria aurantia & 0.054 & 0.000 & 0.054 \\
\hline Ascodesmis sphaerospora & 0.049 & 0.000 & 0.049 \\
\hline Penicillium decumbens & 0.043 & 0.000 & 0.043 \\
\hline Metschnikowia bicuspidata & 0.027 & 0.000 & 0.027 \\
\hline Dothidea insculpta & 0.016 & 0.000 & 0.016 \\
\hline Dendryphiella arenaria & 0.016 & 0.000 & 0.016 \\
\hline Aigialus rhizophorae & 0.011 & 0.000 & 0.011 \\
\hline Scutellospora spinosissima & 0.011 & 0.000 & 0.011 \\
\hline Volvariella volvacea & 0.011 & 0.000 & 0.011 \\
\hline Flammulina velutipes & 0.011 & 0.000 & 0.011 \\
\hline Candida bituminiphila & 0.005 & 0.000 & 0.005 \\
\hline Ascobolus carbonarius & 0.005 & 0.000 & 0.005 \\
\hline Cyttaria sp & 0.005 & 0.000 & 0.005 \\
\hline Halosarpheia japonica & 0.005 & 0.000 & 0.005 \\
\hline Phymatotrichopsis omnivora & 0.005 & 0.000 & 0.005 \\
\hline Sporobolomyces sp & 0.005 & 0.000 & 0.005 \\
\hline Orphella haysii & 0.005 & 0.000 & 0.005 \\
\hline Coccocarpia erythroxyli & 0.005 & 0.000 & 0.005 \\
\hline Termitaria sp & 0.005 & 0.000 & 0.005 \\
\hline
\end{tabular}


Table 2 Fungi that were more common in control participants than in asthma patients (difference in percent of DNA reads in descending order) (Continued)

\begin{tabular}{llll}
\hline Candida glabrata & 0.005 & 0.000 & 0.005 \\
\hline $\begin{array}{l}\text { Schizosaccharomyces } \\
\text { japonicus }\end{array}$ & 0.005 & 0.000 & 0.005 \\
\hline Cladochytrium sp & 0.005 & 0.000 & 0.005 \\
\hline Cyttaria hookeri & 0.011 & 0.006 & 0.005 \\
\hline
\end{tabular}

associated with damp environments that are affected by mould growth, we are unaware of any study that has identified an association between macromycetes and asthma. Future studies should consider analysing air samples from the homes of participants using molecular techniques, so as to take into account the presence of fungi in the ambient environment of participants.

We used universal primers for the eukaryotic $18 \mathrm{~S}$ rRNA gene and were surprised that no eukaryotes other than fungi were identified in cases or controls. We have considered a number of potential reasons why this may be the case and the most likely was that levels of non-fungal eukaryotic DNA, present in the samples, was below the limits of detection. The PCR primers were chosen after considerable deliberation and a probeCheck test showed that they were universal and matched Homo sapiens' $18 \mathrm{~S}$ rRNA gene 100\% [21]. However other potential reasons include: a genuine absence of other eukaryotes and unintended removal of DNA from other eukaryotes as part of the processing of the samples.

Individual level analysis of samples was considered, but rejected as it was anticipated that, if the samples from each individual were analysed separately, the number of eukaryotes in each sample would be below the threshold of detection. Samples for this study were therefore pooled to maximise the number of copies of each species in the pooled samples and consequently maximise the probability of detecting all the species that were present.

The study has a number of weaknesses. The sputum was not fresh when it was examined and although every effort was made to prevent contamination of samples by spores in the air, this is a possibility. The sample size is small and therefore may not be representative of asthma patients. Unfortunately, information on pets was not collected in this study and therefore could not be correlated with the presence of absence of particular fungi. It is possible to speculate that the presence of a pet (particularly a dog) in the subjects' house might be associated with the presence of Malassezia pachydermatis in the sputum of the research subjects, as this organism has been identified as a commensal on the skin of dogs and have could contaminated air in the homes of some of the research participants.

The potential significance of these fungi is unclear. There is tentative emerging evidence that microbiota

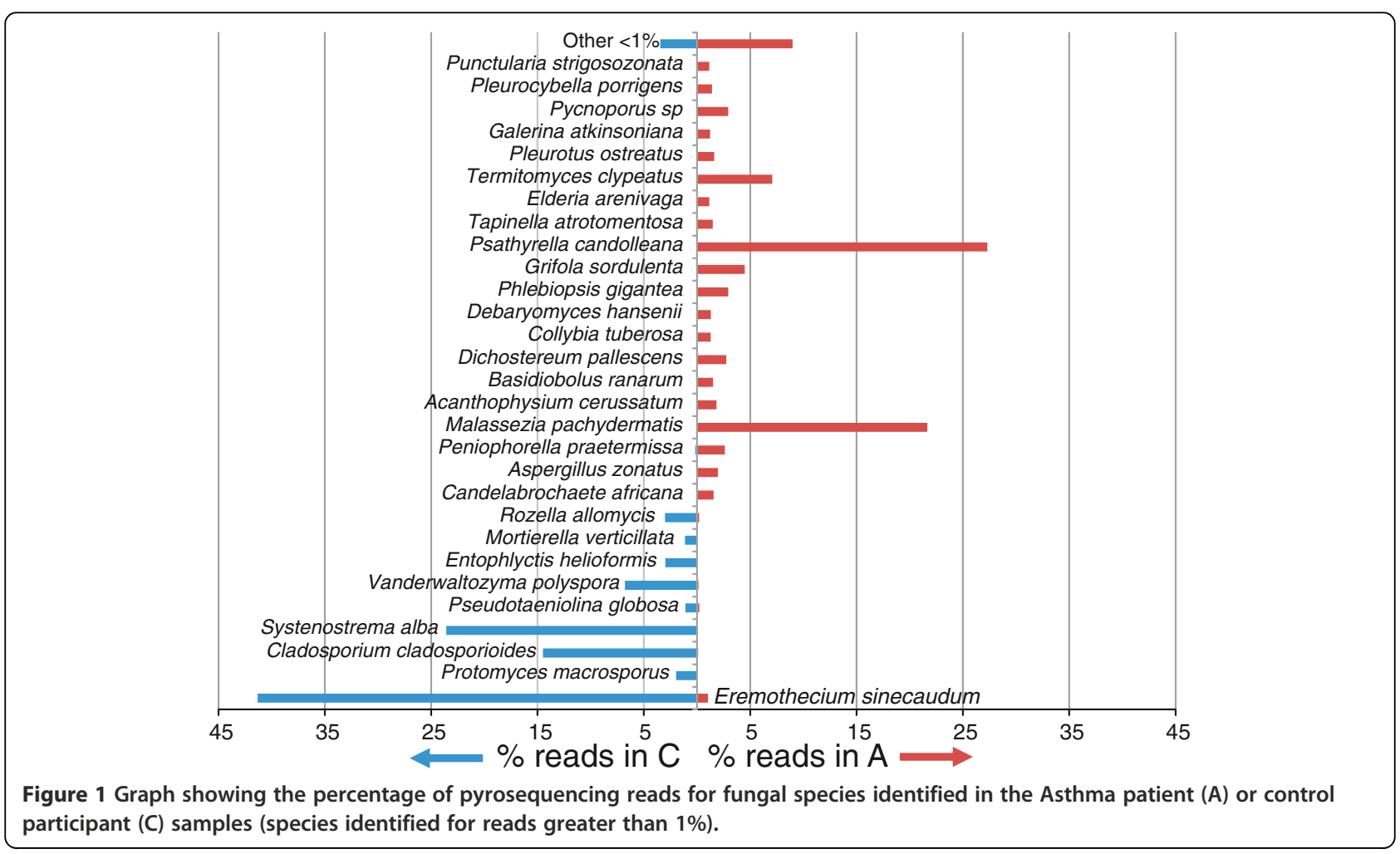


may form part of a complex causal web that results in disease, for example, by their effects on the immune system, without becoming pathogenic in the classical sense. For example, microbial compounds present in sputum may play a role as adjuvant factors and encourage a Th2-biased allergic response [22,23].

\section{Conclusion}

This study provides emerging evidence for the widespread presence of fungi in the sputum of asthma patients and control subjects. Significant differences have been identified in the pattern of fungi present in asthma patients and control subjects drawn from the same community. Although this method demonstrates the possibility of using microscopy samples, further investigation is warranted which applies these techniques to fresh sputum samples. This method may in itself be applicable to analysis of historical samples and may in turn prove of interest in evaluating the microbiome of the lung demographically and between generations.

\section{Competing interests}

The authors declare that they have no competing interests.

\section{Authors' contributions}

HCWW obtained the initial funding, designed the case control study, obtained ethical and NHS R\&D permission and wrote the first draft of the paper. CG, RG and JM undertook analysis of the sputum samples. All authors have contributed to, read and approved the final manuscript.

\section{Acknowledgments}

Funding was by Wandsworth PCT and Cardiff University. We are grateful to a range of colleagues who have contributed to the previously reported study based on this case control study and to the two GP practices that provided access to patients.

The authors would like to acknowledge the assistance of Research and Testing Inc, Lubbock, Texas, USA in carrying out the final stage pyrosequencing.

\section{Author details}

${ }^{1}$ Institute of Primary Care \& Public Health, Cardiff University School of Medicine, Neuadd Meirionnydd, Heath Park, Cardiff CF14 4YS, UK. ${ }^{2}$ Cardiff School of Bioscience, Main Building, Museum Avenue, Cardiff CF10 3AT, UK.

Received: 10 August 2012 Accepted: 28 January 2013

Published: 5 February 2013

\section{References}

1. Hasleton PS: The internal surface area of the adult human lung. J Anat 1972, 112(Pt 3):391-400.

2. Bartsch P, Collignon A, Weber G, Robaye G, Delbrouck JM, Roelandts I, Yujie J: Distribution of metals in human lung: analysis by particle induced $\mathrm{x}$-ray emission. Arch Environ Health 1982, 37(2):111-117.

3. Bunnell J: Editorial. Epidemio-Ecology News 2002, 1(2):1.

4. Griffin DW, Kellogg CA, Garrison VH, Holmes C, Shinn EA: The movement of soil and sediment in Earth's atmosphere: microbiology and ecosystem health. Epidemio-Ecology News 2002, 1(2):1-6.

5. World Health Organisation: Hazard prevention and control in the work environment: airborne dust. Geneva: WHO; 1999.

6. Scott JAG, Hall AJ: The value and complications of percutaneous transthoracic lung aspiration for the etiologic diagnosis of communityacquired pneumonia*. Chest 1999, 116(6):1716-1732.

7. Rogers GB, Carroll MP, Serisier DJ, Hockey PM, Jones G, Kehagia V, Connett GJ, Bruce KD: Use of 165 rRNA gene profiling by terminal restriction fragment length polymorphism analysis to compare bacterial communities in sputum and mouthwash samples from patients with cystic fibrosis. J Clin Microbiol 2006, 44(7):2601-2604.

8. Tunney MM, Field TR, Moriarty TF, Patrick S, Doering G, Muhlebach MS, Wolfgang M, Boucher R, Gilpin DF, McDowell A: Detection of anaerobic bacteria in high numbers in sputum from patients with cystic fibrosis. Am J Respir Crit Care Med 2008, 177:995-1001.

9. Rogers GB, Carroll MP, Serisier DJ, Hockey PM, Kehagia V, Jones GR, Bruce KD: Bacterial activity in cystic fibrosis lung infections. Respir Res 2005, 6(1):49.

10. Hilty M, Burke C, Pedro H, Cardenas P, Bush A, Bossley C, Davies J, Ervine A, Poulter L, Pachter L, et al: Disordered microbial communities in asthmatic airways. PLoS One 2010, 5(1):e8578.

11. van Woerden HC, Ratier-Cruz A, Aleshinloye OB, Martinez-Giron R, Gregory C, Matthews IP: Association between protozoa in sputum and asthma: a casecontrol study. Respir Med 2011, 105(6):877-884.

12. Pirhonen I, Nevalainen A, Husman T, Pekkanen J: Home dampness, moulds and their influence on respiratory infections and symptoms in adults in Finland. Eur Respir J 1996, 9(12):2618-2622.

13. Amann Rl, Krumholz L, Stahl DA: Fluorescent-oligonucleotide probing of whole cells for determinative, phylogenetic, and environmental studies in microbiology. J Bacteriol 1990, 172(2):762-770.

14. Sogin $M L$, Gunderson $\mathrm{JH}$ : Structural diversity of eukaryotic small subunit ribosomal RNAs. Evolutionary implications. Ann N Y Acad Sci 1987, 503:125-139.

15. Lozupone C, Hamady M, Knight R: UniFrac-an online tool for comparing microbial community diversity in a phylogenetic context. BMC Bioinformatics 2006, 7:371.

16. Martin AP: Phylogenetic approaches for describing and comparing the diversity of microbial communities. Appl Environ Microbio/ 2002, 68(8):3673-3682.

17. Gaitanis G, Magiatis P, Hantschke M, Bassukas ID, Velegraki A: The Malassezia genus in skin and systemic diseases. Clin Microbiol Rev 2012, 25(1):106-141.

18. Vasutov M, Urban A: Phylogenetic studies in Psathyrella focusing on sections Pennatae and Spadiceae-new evidence for the paraphyly of the genus. Mycol Res 2008, 112(10):1153-1164.

19. Pitkaranta M, Meklin T, Hyvarinen A, Paulin L, Auvinen P, Nevalainen A, Rintala $\mathrm{H}$ : Analysis of fungal flora in indoor dust by ribosomal DNA sequence analysis, quantitative PCR, and culture. Appl Environ Microbiol 2008, 74(1):233-244

20. Burr ML, Matthews IP, Arthur RA, Watson HL, Gregory CJ, Dunstan FD, Palmer SR: Effects on patients with asthma of eradicating visible indoor mould: a randomised controlled trial. Thorax 2007, 62(9):767-772.

21. Quast C, Pruesse E, Yilmaz P, Gerken J, Schweer T, Yarza P, Peplies J, Glockner FO: The SILVA ribosomal RNA gene database project: improved data processing and web-based tools. Nucleic Acids Res 2013, 41(D1):D590-596.

22. Jacquet A: The role of the house dust mite-induced innate immunity in development of allergic response. Int Arch Allergy Immunol 2010, 155(2):95-105

23. Jacquet A: Interactions of airway epithelium with protease allergens in the allergic response. Clin Exp Allergy 2011, 41(3):305-311.

doi:10.1186/1471-2334-13-69

Cite this article as: van Woerden et al:: Differences in fungi present in induced sputum samples from asthma patients and non-atopic controls: a community based case control study. BMC Infectious Diseases 2013 13:69.

\section{Submit your next manuscript to BioMed Central and take full advantage of:}

- Convenient online submission

- Thorough peer review

- No space constraints or color figure charges

- Immediate publication on acceptance

- Inclusion in PubMed, CAS, Scopus and Google Scholar

- Research which is freely available for redistribution 